\title{
Phytoplankton productivity in newly dug fish ponds within Lake Victoria wetlands (Uganda)
}

\author{
Grace Asiyo Ssanyu ${ }^{1 *}$ and Michael Schagerl ${ }^{2}$ \\ ${ }^{1}$ Department of Biological Sciences, Kyambogo University, Kampala, Uganda, \\ ${ }^{2}$ Department of Marine Biology, University of Vienna, Althanstraße 14 A-1090 Vienna, Austria.
}

Accepted 18 March, 2010

\begin{abstract}
The declining Lake Victoria fisheries resource led to a growing recognition of aquaculture as a source of livelihood to riparian communities. Finger ponds speculated to naturally stock fish during flooding and retain them during dry seasons were introduced within the lake's wetlands. In order to develop a better understanding of these ponds' dynamics, algal primary productivity was studied in eight newly dug wetland fishponds $(8 \times 24 \mathrm{~m})$ located in two villages along the northern shores of Lake Victoria (Uganda) before stocking them with fish. Gross primary productivity was low for both sites ranging between 0.00 and $2.63 \mathrm{mg} \mathrm{O}_{2} \mathrm{~L}^{-1} \mathrm{~h}^{-1}$. The net areal primary productivity of Gaba ponds ranged from -0.34 to $4.66 \mathrm{mg} \mathrm{O}_{2} \mathrm{~m}^{-2} \mathrm{~d}^{-1}$ while that of Walukuba ponds ranged from 1.16 to $6.25 \mathrm{mg} \mathrm{O}_{2} \mathrm{~m}^{-2} \mathrm{~d}^{-1}$. Chlorophyll a mean values were $23.46 \pm 12.50 \mu \mathrm{g} \mathrm{L}^{-1}$ and $75.56 \pm 44.35 \mu \mathrm{g} \mathrm{L}^{-1}$ and mean turbidity ranges were $132.1-$ 242.25 and 432.54 - 158.49 NTU for Gaba and Walukuba ponds respectively. Reduced light supply due to the high inorganic turbidity may have been the main limitation for photoautotrophic primary productivity and ponds potential fish yield of $10-24 \mathrm{~kg} \mathrm{ha}^{-1}$ fish per year.
\end{abstract}

Key words: phytoplankton, primary productivity, fish ponds, light-limitation, Uganda.

\section{INTRODUCTION}

Over 20 million people depend on Lake Victoria for various resources especially fisheries. In the past years the Lake Victoria has been under pressure due to various economic activities and ecological factors associated with over exploitation of the fisheries sector, resulting in the decline of the fisheries resource (Geheb and Binns, 1997). There is a growing recognition of the considerable potential of rural aquaculture to diversify livelihood options for poor farmers and increase their income while reducing their vulnerability and also improving land and water management (Briones et al., 2004). However much of the potential of inland aquaculture in sub-Saharan Africa remains unexplored (NARO, 2004) and there is need to diversify culture environments which are economically justified from the conventional ones. In response to the reduction in fish production in Lake Victoria, the "finger ponds project" was funded in 2002 by the European Union (ICA4-2000-20018). Finger ponds

${ }^{\overline{ }}$ Corresponding author. Email: ssangrace@mail.com. Tel: +256 712186840. are similar to the "hortillonnages" systems of Mexico and Rwanda. In this case, subsistence fish production is enhanced. The finger ponds within wetlands were speculated to have the ability to naturally stock fish during flooding and retaining the fish during dry seasons (Pokorný et al., 2003). The innovation was meant to offer an alternative activity to resource poor communities of the Lake Victoria wetlands (Kipkemboi et al., 2006), especially women groups. The yields of tilapia and vegetables from the finger ponds system form a valuable addition to the household food and income. Algal primary productivity is the driving force behind secondary productivity in aquaculture systems stocked with herbivorous fish. It is influenced by the availability of nutrients (Knud-Hansen, 1997) and among a large number of nutrients required to stimulate growth, low concentrations of nitrogen, phosphorus and occasionally carbon are commonly responsible for limiting algal growth (Lin et al., 1997). Besides nutrients availability, light supply plays a central role in phytoplankton growth. In both mono- and poly-culture ponds, water mixing resulting in a resuspension of particles largely reduces photoautotroph because of limited light supply (Smith and 


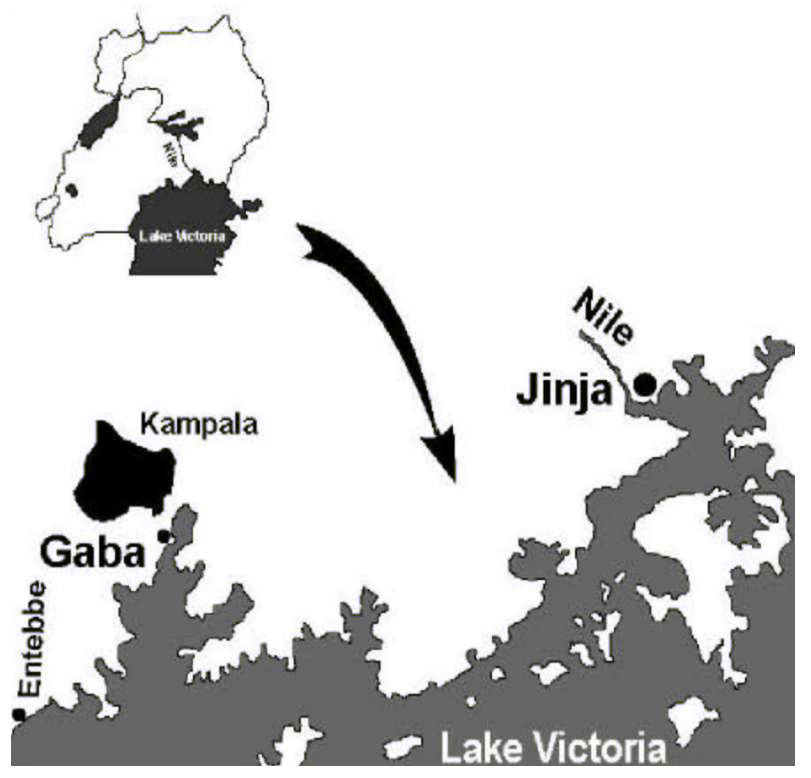

Figure 1. Map of the study area.

Piedrahita, 1988; Hargreaves, 1998). Phytoplankton productivity and total biomass are in a direct relation with the environmental factors (Talling, 1966; Lungayia et al., 2000). Variations in production of finfish, mainly Tilapia and Carp, highly correlate with primary productivity (Behrends et al., 1985). While pond dynamics as a scientific discipline in many African countries deserves more attention (Knud-Hassen, 1997), there is need for aquaculturists to develop a better understanding of the primary and secondary productivity from a limnoligical perspective. The objective of this study was to determine the phytoplankton primary productivity in the finger ponds at the onset of the first grow-out season in relation to the physico-chemical parameters. At this time, ponds were not treated with manure or any fertiliser.

\section{MATERIALS AND METHODS}

\section{Study area}

The research was carried out in two wetlands situated within the Lake Victoria basin, located at an altitude of $1134 \mathrm{~m}$ above sea level (Figure 1): Gaba (32 ${ }^{\circ} 35^{\prime}$ East and 00 $20^{\prime}$ North) and

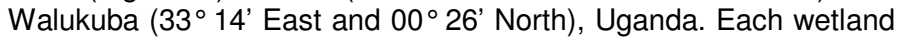
consisted of four ponds: Gaba site- G1, G2, G3, G4; and Walukuba site- W1, W2, W3, and W4. The size of each pond was $24 \mathrm{~m}$ by $8 \mathrm{~m}$ with an average depth of $1.0 \mathrm{~m}$. Sampling was fortnightly throughout April to September 2003.

\section{Field sampling}

In situ measurements of $\mathrm{pH}$, temperature, electrical conductivity and dissolved oxygen were done using a $\mathrm{pH}$ meter (Jenway, 3071), a conductivity probe (WTW Cond, 90) and an oxygen probe respectively (WTW Oximeter, 91). Depths were determined using a secchi disc. Integrated water samples were collected using a $5 \mathrm{~L}$ canister with a suction unit. Soluble reactive phosphorus (SRP), silica (SRSi), nitrate $\left(\mathrm{NO}_{3}-\mathrm{N}\right)$, nitrite $\left(\mathrm{NO}_{2}-\mathrm{N}\right)$ and ammonia $\left(\mathrm{NH}_{4}\right.$ $\mathrm{N})$ were determined following the protocols established by the American Public Health Association (APHA, 1995). Total phosphorus (TP) and total nitrogen (TN) were determined using wet combustion method (APHA, 1995). Turbidity was measured by spectrophometry where hydrazine sulphate and hexamethylenetetramine solutions were mixed and used as the stock solution with 4000 nephelometric turbidity units (NTU) for the calibration in the DR $2000 \mathrm{HACH}$ spectrophometer. Algal biomass was estimated using chlorophyll-a method (Wetzel and Likens, 1991).

Primary productivity was determined with the Winkler's light and dark bottle method (Schwoerbel, 1994). Water samples were collected at $10 \mathrm{~cm}$ below the water surface by using a $5 \mathrm{~L}$ canister by lowering its suction unit into a pond. The bottles were exposed for 2 hours at $10 \mathrm{~cm}$ intervals between a time window of 10.00 hours and $15.00 \mathrm{~h}$. The differences between oxygen content in the light and initial unexposed bottles were integrated over the photic depth to give net primary productivity (NPP) per square meter per hour. Potential fish yields (FY) were obtained by applying the formula: $\log F Y=0.113 P G+0.91$ where $F Y$ is expressed in $\mathrm{kg}$ weight $\mathrm{ha}^{-1} \mathrm{yr}^{-1}$ and $\mathrm{PG}$ the gross productivity as $\mathrm{O}_{2} \mathrm{mg}^{-2} \mathrm{~d}^{-1}$ (Melack, 1976). The data were analyzed using Statistica (version 5). Spatial variations of the chemical variables were analyzed using the non-parametric Kruskal-Wallis test. Spearman's rank correlation tests were done to check for the presence of significant relationships between the various parameters and when present, these were further analyzed using regression analysis for the trends of the relationships.

\section{RESULTS}

The temperature ranged from 23.47 to $27.17{ }^{\circ} \mathrm{C}, \mathrm{pH}$ from 7.95 to 9.14 and dissolved oxygen from 3.63 to $6.95 \mathrm{mgL}^{-}$ ${ }^{1}$ for both sites. Higher levels of turbidity were recorded in the Gaba ponds than in the Walukuba ponds (Figure 2, Table 1). The $\mathrm{NO}_{3}-\mathrm{N}$ was low, ranging between $0-500$ $\mu \mathrm{g} \mathrm{L}^{-1}$ and $\mathrm{NO}_{2}-\mathrm{N}$ ranged from 0 and $330 \mu \mathrm{g} \mathrm{L}^{-1}$ at both sites (Table 2). The SRSi concentration was generally high in the studied areas, ranging from $12.9-54.1 \mathrm{mg} \mathrm{L}^{-1}$. SRP concentrations ranged from 12 to $143 \mathrm{\mu g} \mathrm{L}^{-1}$ in the Gaba ponds and 15 to $318 \mu \mathrm{g} \mathrm{L}^{-1}$ in the Walukuba ponds. A significant spatial variation was recorded in the TP concentrations $\left(x^{2}=42.8, p<0.001\right)$, with lower values in Gaba than Walukuba. The Chlorophyll a concentration was significantly higher (Figure 3) in Walukuba ponds (range of $7.9-191.0 \mu \mathrm{g} \mathrm{L}^{-1}$ ) than that of Gaba site (range of $4.8-95.0 \mu \mathrm{g} \mathrm{L}^{-1}$ ).

\section{Species composition}

There were 37 and 31 taxa in Gaba and Walukuba ponds respectively, distributed among six taxonomic groups as follows: $17 \%$ Cyanobacteria, 18\% Bacillariophyceae, $16 \%$ Euglenophyta and 52\% Chlorophytes in Gaba ponds. $13 \%$ Cyanobacteria, 19\% Bacillariophyceae, 19\% Euglenophyta, 6\% Chrysophyceae and 39\% Chlorophytes were found in Walukuba ponds. The 


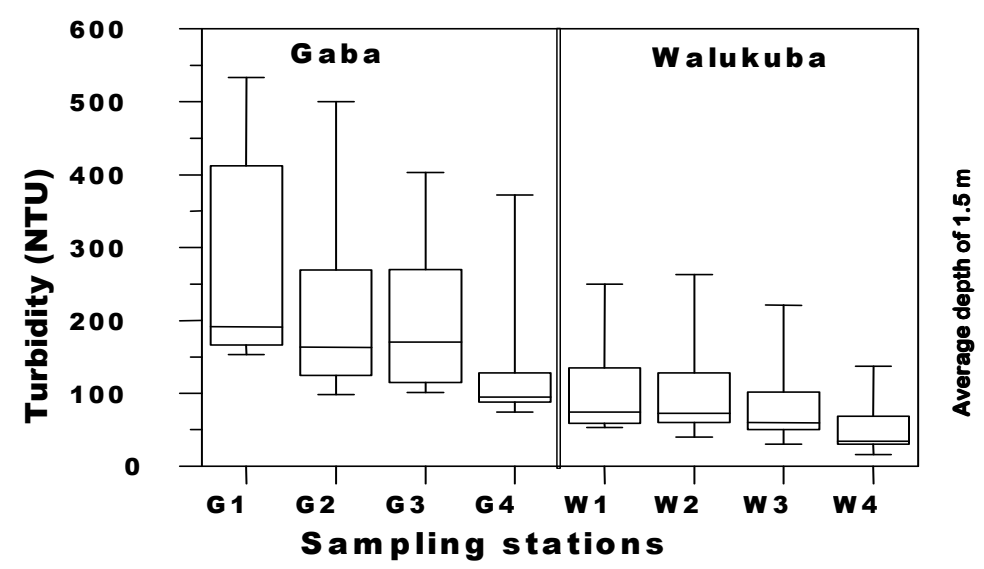

Figure 2. Turbidity (NTU) mean levels in the Gaba site (left) and Walukuba site (right) ponds for all the sampling times of April to September 2003.

Table 1. Means of physical variables of the ponds (mean \pm STD).

\begin{tabular}{ccccccc}
\hline $\begin{array}{c}\text { Chemical } \\
\text { parameters }\end{array}$ & $\begin{array}{c}\text { Dissolved } \\
\mathbf{O x y g e n}_{\left(\mathbf{m g L}^{-1}\right)}\end{array}$ & $\mathbf{p H}$ & $\begin{array}{c}\text { Conductivity } \\
(\boldsymbol{\mu S} / \mathbf{c m})\end{array}$ & Turbidity (NTU) & $\begin{array}{c}\mathbf{S i O}_{2} \\
\left(\mathbf{m g L}^{-1}\right)\end{array}$ & $\begin{array}{c}\text { Secchi depth } \\
(\mathbf{c m})\end{array}$ \\
\hline W1 & $6.36 \pm 0.59^{\mathrm{a}}$ & $8.58 \pm 0.12$ & $985.33 \pm 75.70^{\mathrm{a}}$ & $102.91 \pm 55.59^{\mathrm{a}}$ & $47.68 \pm 8.0^{\mathrm{a}}$ & $19.8 \pm 4.9^{\mathrm{a}}$ \\
W2 & $5.89 \pm 0.65^{\mathrm{a}}$ & $8.85 \pm 0.14$ & $1153.13 \pm 98.87^{\mathrm{a}}$ & $93.09 \pm 51.40^{\mathrm{a}}$ & $31.11 \pm 4.7^{\mathrm{a}}$ & $21.8 \pm 1.4^{\mathrm{a}}$ \\
W3 & $5.58 \pm 0.78^{\mathrm{a}}$ & $9.00 \pm 0.13$ & $1483.85 \pm 95.23^{\mathrm{a}}$ & $83.59 \pm 36.92^{\mathrm{a}}$ & $32.17 \pm 2.92^{\mathrm{a}}$ & $23.2 \pm 3.3^{\mathrm{a}}$ \\
W4 & $5.09 \pm 1.48^{\mathrm{a}}$ & $9.09 \pm 0.14$ & $1529.08 \pm 78.18^{\mathrm{a}}$ & $48.57 \pm 16.03^{\mathrm{a}}$ & $27.90 \pm 1.68^{\mathrm{a}}$ & $27.9 \pm 3.6^{\mathrm{a}}$ \\
G1 & $3.98 \pm 0.35^{\mathrm{a}}$ & $7.56 \pm 0.39$ & $288.47 \pm 33.72^{\mathrm{b}}$ & $288.52 \pm 46.27^{\mathrm{b}}$ & $43.21 \pm 3.78^{\mathrm{a}}$ & $10.6 \pm 1.40^{\mathrm{a}}$ \\
G2 & $4.58 \pm 1.20^{\mathrm{a}}$ & $8.28 \pm 0.28$ & $431.87 \pm 22.10^{\mathrm{b}}$ & $201.86 \pm 61.51^{\mathrm{b}}$ & $19.40 \pm 3.98^{\mathrm{a}}$ & $20.4 \pm 1.2^{\mathrm{a}}$ \\
G3 & $4.59 \pm 0.84^{\mathrm{a}}$ & $8.12 \pm 0.45$ & $426.43 \pm 26.67^{\mathrm{b}}$ & $214.14 \pm 78.30^{\mathrm{b}}$ & $13.31 \pm 1.17^{\mathrm{a}}$ & $19.3 \pm 2.4^{\mathrm{a}}$ \\
G4 & $5.12 \pm 0.67^{\mathrm{a}}$ & $8.15 \pm 0.26$ & $470.90 \pm 35.05^{\mathrm{b}}$ & $134.76 \pm 62.3^{\mathrm{b}}$ & $15.94 \pm 0.78^{\mathrm{a}}$ & $21.3 \pm 1.0^{\mathrm{a}}$ \\
\hline
\end{tabular}

Values in the same column with the same superscript were not significantly different $(P>0.05)$, STD, standard deviation.

Table 2. Means of water quality parameters of the ponds.

\begin{tabular}{|c|c|c|c|c|c|c|c|c|}
\hline Site/pond & $\begin{array}{l}\mathrm{NH}_{4}-\mathrm{N} \\
\left(\mu \mathrm{g} \mathrm{L}^{-1}\right)\end{array}$ & $\begin{array}{l}\mathrm{NO}_{3}-\mathrm{N} \\
\left(\mu \mathrm{g} \mathrm{L}^{-1}\right)\end{array}$ & $\begin{array}{l}\mathrm{NO}_{2}-\mathrm{N} \\
\left(\mu \mathrm{g} \mathrm{L}^{-1}\right)\end{array}$ & $\begin{array}{c}\text { SRP } \\
\left(\mu \mathrm{g} \mathrm{L}^{-1}\right)\end{array}$ & $\begin{array}{l}\text { Alkalinity } \\
\left(\mathrm{mval} \mathrm{L}^{-1}\right)\end{array}$ & $\begin{array}{c}\mathrm{TP} \\
\left(\mu \mathrm{g} \mathrm{L}^{-1}\right)\end{array}$ & $\begin{array}{c}\mathrm{TN} \\
\left(\mathrm{mg} \mathrm{L}^{-1}\right)\end{array}$ & $\begin{array}{c}\text { Chl. a } \\
\left(\mu \mathrm{g} \mathrm{L}^{-1}\right)\end{array}$ \\
\hline W1 & $260.4^{a}$ & $66.4^{a}$ & $16.3^{a}$ & $25.9^{a}$ & $1.97^{\mathrm{a}}$ & $603.1^{a}$ & $2.29^{a}$ & $85.60^{a}$ \\
\hline w2 & $847.9^{a}$ & $21.0^{a}$ & $2.1^{\mathrm{a}}$ & $33.5^{\mathrm{a}}$ & $2.31^{a}$ & $578.7^{\mathrm{a}}$ & $1.84^{\mathrm{a}}$ & $72.67^{\mathrm{a}}$ \\
\hline W3 & $162.5^{\mathrm{a}}$ & $62.7^{\mathrm{a}}$ & $30.0^{a}$ & $175.8^{a}$ & $2.94^{a}$ & $798.2^{a}$ & $2.21^{a}$ & $67.23^{\mathrm{a}}$ \\
\hline W4 & $178.3^{\mathrm{a}}$ & $188.2^{\mathrm{a}}$ & $89.4^{a}$ & $55.1^{\mathrm{a}}$ & $2.92^{a}$ & $669.2^{\mathrm{a}}$ & $2.30^{\mathrm{a}}$ & $73.37^{\mathrm{a}}$ \\
\hline G1 & $382.6^{\mathrm{b}}$ & $136.8^{a}$ & $45.7^{a}$ & $72.4^{\mathrm{a}}$ & $0.82^{a}$ & $363.1^{b}$ & $2.07^{\mathrm{a}}$ & $17.03^{b}$ \\
\hline G2 & $308.2^{b}$ & $104.8^{a}$ & $12.6^{a}$ & $38.4^{a}$ & $0.95^{a}$ & $306.5^{b}$ & $2.66^{a}$ & $39.96^{b}$ \\
\hline G3 & $345.0^{b}$ & $55.4^{\mathrm{a}}$ & $12.6^{a}$ & $37.5^{\mathrm{a}}$ & $1.10^{\mathrm{a}}$ & $209.8^{b}$ & $2.23^{a}$ & $25.44^{b}$ \\
\hline G4 & $328.4^{\mathrm{b}}$ & $15.25^{\mathrm{a}}$ & $8.6^{\mathrm{a}}$ & $15.9^{a}$ & $1.16^{\mathrm{a}}$ & $172.6^{\mathrm{b}}$ & $2.17^{\mathrm{a}}$ & $10.16^{b}$ \\
\hline
\end{tabular}

Values in the same column with the same superscript were not significantly different $(P>0.05)$.

dorminant species are among Cyanobacteria were Anaphanocapis spp, Microcystis spp and planktonlyngbya limnetica, and among the diatoms the Nitzschia spp and Navicula spp were in high numbers.
The green algae were dorminated by Ankistrodesmus falcatus, Scenedesmus spp and Monoraphidium spp while among the other groups Euglena spp and Tracheomonas spp are also very common. 


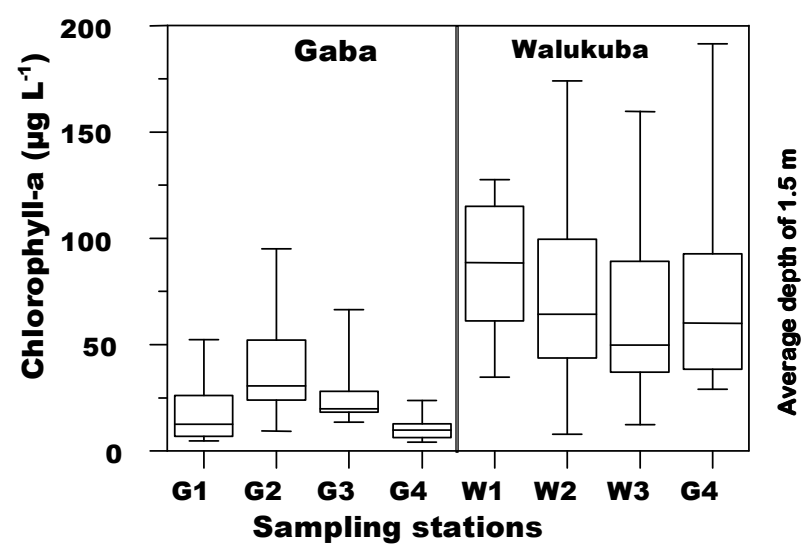

Figure 3. The median chlorophyll a content in the Gaba (left) and Walukuba (right) ponds for the sampling time April to September 2003.

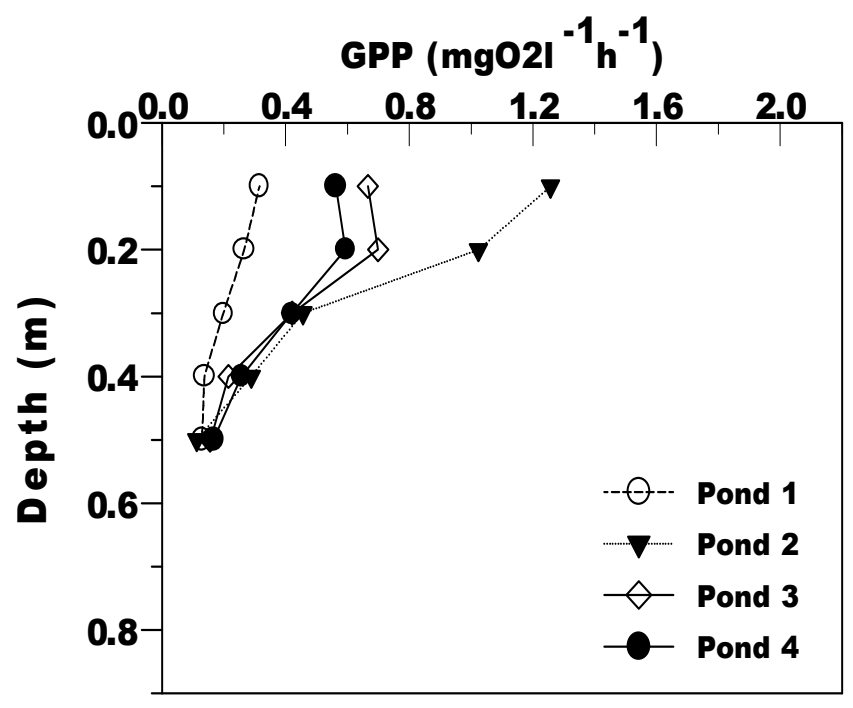

Figure 4. Mean Gross Primary Productivity (GPP) depth profiles of the Gaba ponds from April to September 2003.

\section{Primary productivity}

An abrupt decrease in primary production with depth was detected in all ponds with highest values within the first $10 \mathrm{~cm}$ (Figures 4 and 5). No significant temporal variations could be detected and surface inhibition was noticed only in G3 and G4. However, gross productivity was significantly higher in the Walukuba ponds as compared to that of Gaba, with values between 0.01 to $2.63 \mathrm{mg} \mathrm{O}_{2} \mathrm{~L}^{-1} \mathrm{~h}^{-1}$ and 0.00 to $2.09 \mathrm{mg} \mathrm{O}_{2} \mathrm{~L}^{-1} \mathrm{~h}^{-1}$ respectively $\left(x^{2}=21.0, p<0.001\right)$. The median areal net productivity was higher in Walukuba ponds than in the Gaba ponds for the whole sampling time (Figure. 6). The specific productivity based on $\mathrm{Chl}$ a $(\mathrm{P} \max )$ was generally low although it was higher in the Gaba ponds

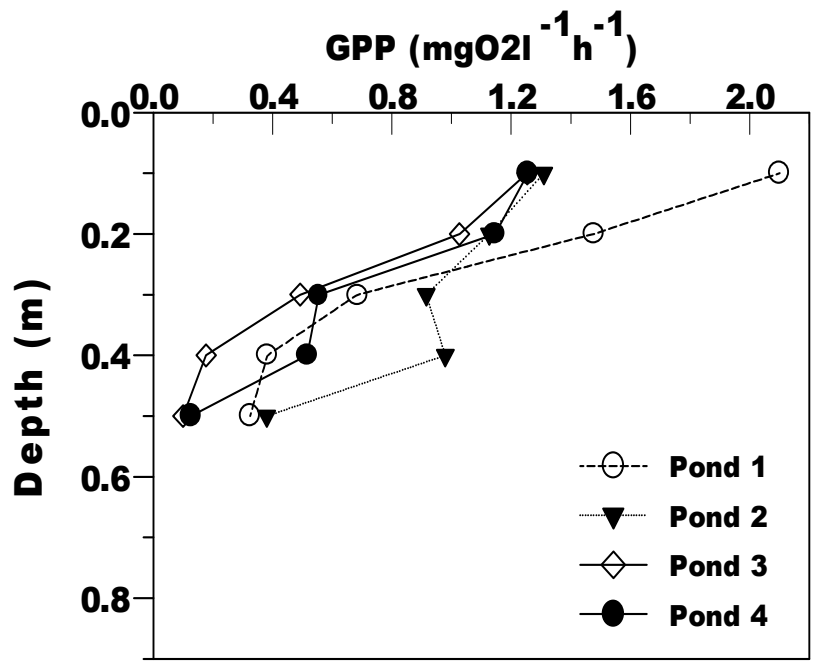

Figure 5. Mean Gross Primary Productivity (GPP) depth profiles of the Walukuba ponds during the sampling time, April to September 2003.

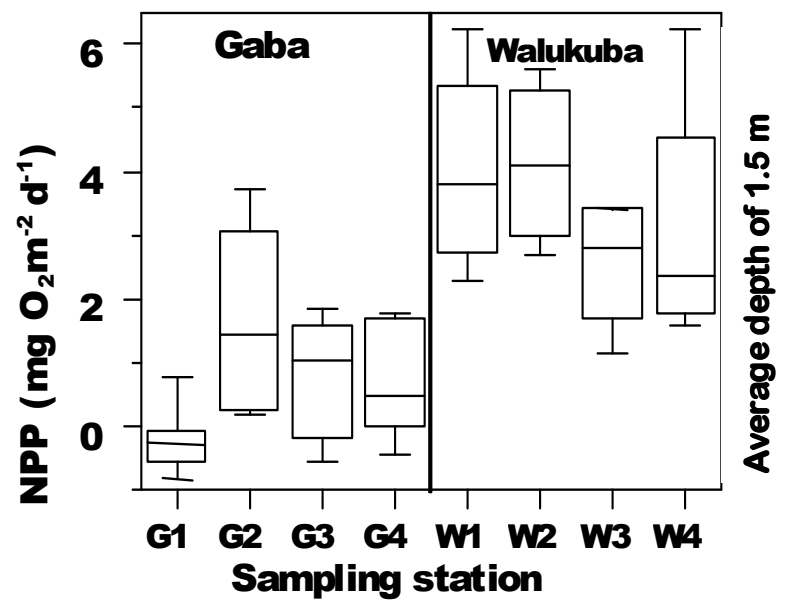

Figure 6. Median Net Areal productivity for the Gaba ponds (left) and Walukuba ponds (right) during the sampling time April to September 2003.

than Walukuba ponds (Table 3). A significant negative correlation between gross productivity and turbidity (spearman rank correlation of $x^{2}=-0.31, p<0.001$ ) was realised. As a result low light utilization efficiency and onset of light saturation in the ponds were determined. Potential fish yields were very low values: the Gaba ponds would produce $10-16 \mathrm{~kg} \mathrm{ha}^{-1}$ of fish per year while Walukuba ponds would produce 16 - $24 \mathrm{~kg} \mathrm{ha}^{-1}$ fish per year (Table 4).

\section{DISCUSSION}

The shallow depth of the ponds allowed constant nutrient 
Table 3. The maximum gross productivity (P max), specific Pmax (Pbm) and light utilization efficient ( $\alpha$ ) for the Gaba and Walukuba ponds for the sampling period.

\begin{tabular}{|c|c|c|c|}
\hline Site/pond & $\begin{array}{c}P_{\max } \\
\left(\mathrm{mg} \mathrm{O}_{2} \mathrm{~L}^{-1} \mathrm{~h}^{-1}\right)\end{array}$ & $\begin{array}{c}\mathrm{Pbm} \\
\left(\mathrm{mg} \mathrm{O}_{2} \mathrm{~h}^{-1} \mu \mathrm{g} \mathrm{chl}-\mathrm{a}^{-1}\right)\end{array}$ & 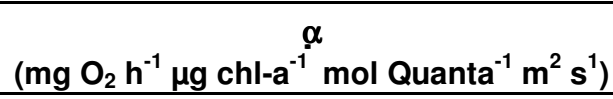 \\
\hline W1 & 2.2 & 24.5 & 0.6 \\
\hline W2 & 2.1 & 23.6 & 0.3 \\
\hline W3 & 1.7 & 19.1 & 0.4 \\
\hline W4 & 2.5 & 28.0 & 0.7 \\
\hline G1 & 2.1 & 124.4 & 0.1 \\
\hline G2 & 2.0 & 118.4 & 0.5 \\
\hline G3 & 0.9 & 53.3 & 0.2 \\
\hline G4 & 0.8 & 47.4 & 0.1 \\
\hline
\end{tabular}

Table 4. Estimated fish yield mean values of the ponds for the whole sampling time.

\begin{tabular}{ccc}
\hline Site/Pond & GPP $\left(\mathbf{g m}^{-\mathbf{2}} \mathbf{d}^{\mathbf{- 1}}\right)$ & Fish Yield (Kg ha-1 $\mathbf{~ y r - 1 )}$ \\
\hline W1 & 4.04 & 23 \\
W2 & 4.12 & 24 \\
W3 & 2.55 & 16 \\
W4 & 3.14 & 18 \\
G1 & 0.89 & 10 \\
G2 & 2.65 & 16 \\
G3 & 1.88 & 13 \\
G4 & 1.76 & 13 \\
\hline
\end{tabular}

recycling coupled with greater heat absorption from the surrounding hot humid air. High temperature and permanent mixing are essential in promoting recycling and availability of nutrients for growing algae (Erikson et al., 1998). The shallower Walukuba ponds recorded higher levels of inorganic nitrogen in particular $\mathrm{NH}_{4}-\mathrm{N}$ than the Gaba ponds. A rise in denitrification processes of $\mathrm{NO}_{3}-\mathrm{N}$ in micro anaerobic pockets might explain this $\mathrm{NH}_{4}-\mathrm{N}$ intensification and $\mathrm{NO}_{3}-\mathrm{N}$ reduction (Quiros, 2003). Remineralisation of settled organic matter is a common occurrence in ponds. This leads to creation of anaerobic pockets which favour denitrification, releasing ammonia in response to a concetration gradient extending from the sediment layer into the water column. The finger ponds' high phosphorus was attributed to the release from the sediments which is enhanced especially in shallow water bodies with high turbulence and small anaerobic bottom zones. The ponds with less dissolved oxygen were found with higher levels of phosphorus. Phosphorus exchange across the sediment-water interface is regulated by oxidation-reduction interactions regulated by oxygen supply (Wetzel, 2001). Soluble phosphorus accumulates in the anaerobic pockets due to oxidation of iron that releases phosphate into water. In the fingerponds, this could have been the case since significant correlation was found between the soluble reactive phosphorus concentration and the dissolved oxygen. The phosphorus content in the Gaba ponds was found to be higher than those in Walukuba. The lower levels of_oxygen together with the higher levels of turbidity and total suspended solids in the Gaba ponds as compared to the Walukuba ones could have attributed to this result.

The suspended solid with adsorbed phosphorus may have released it into the water column during suspension given that a strong correlation between phosphorus concentration and turbidity. According to Calijuri and Dos Santos (2001), phosphorus is also released in the water column because of desorption processes of phosphate from suspended solids. Interaction of light and temperature frequently may have resulted in one of several possible vertical profiles of photosynthesis in the ponds. The depth at which maximum rates of photosynthesis occurs varies with the transparency of water, which is governed by the concentration of dissolved and particulate organic matter and the abiotic turbidity (Wetzel, 2001). Surface photoinhibition effects may have occured followed by rapid light attenuation due to high turbidity reducing the severity of enzymatic damage, therefore the high productivity in the ponds was at the $10 \mathrm{~cm}$ depth. Generally low levels of primary productivity recorded in the ponds were attributed to low light supply. Small ponds with a greater shoreline to surface-area ratio, soil erosion has a relatively high impact on the inorganic turbidity levels (Knud-Hansen, 1997). The high turbidity was enhanced by wind induced mixing, slow settling of clay particles and the bear earthen pond banks which easily released clay particles into the ponds' water. Since the nutrient supply was relatively high, light limitation was rather the primary controlling factor for algal productivity. High sediment resuspension leads to high turbidity and low light availability, thus low areal productivity observed in reseviors (Shiah et al., 1996). There is strong evidence indicating that turbidity and nutrient supply affect the variability of areal productivity. Gaba ponds with high turbidity had lower areal productivity and yet nutrient levels were quite higher than those in Walukuba ponds with low turbidity. The physiological acclimation to 
changes in light intensity could have been an important factor determing phytoplankon photosynthesis. Lowirradiance acclimation of the Gaba ponds phytoplankton community enabled them to have higher specific productivity per unit biomass. Much of the productivity was contributed by the dominating cyanobacteria in the ponds.

The relative contribution of small sized phytoplankton, cyanobacteria and diatoms is higher at high temperature, low nutrients and low light conditions (Tundisi et al., 2002). The photosynthetic efficiencies were higher in the Walukuba ponds than Gaba ponds and this was mainly due to the fact that as the quantity of biomass increase, the integral photosynthesis efficiencies generally increase until the maximum levels are restricted by light limitation imposed by self shading or inorganic turbidity. The high turbidity in all ponds limited light penetration and thus photosynthetic efficiency. Due to lower turbidity level of Walukuba ponds the higher photosynthetic efficiencies resulted in higher biomass than the of Gaba ponds.

There is a strong relationship between algal net productivity and the net yield of fish whose diets consist of food produced within the pond system according to Knud-Hansen (1997). The low primary production resulted in low potential fish yields of the ponds. A decrease in turbidity and manure addition would boost natural productivity, which further might lead to an average fish yield of 3.2 ton ha-1 $\mathrm{yr}^{-1}$ (Davies et al., 2006; Edwards et al., 1991). The low yield predictions were attributed to the fact that the ponds were very turbid and lacked a nutrient booster.

\section{Conclusion}

The ponds low phytoplankton primary productivity was attributed to light limitation caused by high inorganic turbidity in the water column rather than nutrient inadequacy. An increased primary productivity fore fronting high fish production could be achieved with a combination of manuring ponds using locally available materials and growing soil holding grass along pond banks to reduce turbidity.

\section{ACKNOWLEDGEMENTS}

We acknowledge the Austrian and the Netherlands Governments for financing the research. We appreciate the support of Gerold Winkler, Sabine Wanzenboeck, Yusuf Kizito, the staff of National Water and Sewage Corporation, Kampala, Fisheries Resources Research Institute, Jinja, Makerere University Institute of Natural Resources and Environment and the Marine Biology Department of the University of Vienna, Austria.

\section{REFERENCES}

APHA (1995). Standard methods for the examination of Water and Wastewater. American Public Health Association, 19th Edition, Washington D C, U.S.A.

Behrends LL, Kingsley JB, Price III AH (1985). Polyculture of freshwater prawns; Tilapia, Channel Catfish and Chinese Carps. Journal of the world mariculture society 16: 437- 450.

Briones M, Dey MM, Ahmed M, (2004). The future for fish in the livelihoods of the poor in Asia. NAGA, Worldfish Q. 27(3; \&4): 48-50.

Calijuri MC, Dos Santos ACA (2001). Temporal variations in phytoplankton primary production in a tropical reservoir (Barra Bonita, SP - Brazil). Hydrobiol. 445: 11-26.

Davies OA, Alfred-Ockiya JF, Asele A (2006). Induced growth of phytoplankton using two fertilizers (NPK and agrolyser) under laboratory conditions. Afr. J. Biotechnol. 5: 373-377.

Edwards $\mathrm{R}$, Demaine $\mathrm{H}$, Komolmari $\mathrm{S}$, Little DC, Innes-Taylor NL, Turongruang D, Yakupitiyage A, Wallen TJ (1991). Towards the improvement of fish culture by small scale farmers in Northeast Thailand. Asian Farm. Syst. Assoc. 1: 287-302.

Erikson R, Hooker E, Mejia M, Zelaya A, Vammen K (1998). Optimal conditions for primary production in a polymictic tropical lake (Lake Xolotl'an, Nicaragua). Hydrobiol. 382: 1-16.

Gehebs K, Binns T (1997). Fishing farmers or farming fishermen? the quest for household income and nutritional security on the Kenyan shores of Lake Victoria African affairs. 96: 73-93.

Hargreaves JA (1998). Nitrogen biochemistry of aquaculture ponds. Aquaculture. 166: 181-212.

Kipkemboi J, Van Dam AA, Denny P (2006). Biophysical suitability of smallholder integrated aquaculture-agriculture systems (fingerponds) in East Africa's Lake Victoria freshwater wetlands. Int. J. Ecol. Environ. Sci. 32 (1): 75-83.

Knud-Hansen CF (1997). Experimental design and analysis in aquaculture. In Egan HS, Boyd CE (eds) Dynamics of pond aquaculture: CRS Press Boca - Raton New York, pp. 325-375.

Lin CK, Teichert-Coddington DR, Green BW, Veverica KL (1997). Fertilization regimes. In Egna HS, Boyd CE (eds) Dynamics of Pond Aquaculture: CRC Press, Boca Raton - New Yor, p. 73-107.

Lungayia HBO, M'Harzi TM, Gichuki J (2000). Phytoplankton community structure and environment in the Kenyan waters of Lake Victoria. Freshwater Biol. 43: 529-543.

Melack JM (1976). Primary productivity and fish yields in tropical lakes. Transactions of the American Fisheries Society. 105: 575-580.

NARO (2004). The National Fisheries Policy, Ministry of Agriculture, Animal Industry and Fisheries. The Republic of Uganda. p. 107.

Quiros R (2003). The relationship between nitrate and ammonia concentration in the pelagic zone of lakes. Limnetica. 22: 37-50.

Schwoerbel, J. (1994). Methoden der Hydrobiologie, Süßwasserbiologie. Gustav Fischer Publisher. p. 387.

Shiah F, Gong G, Liu K, (1996). Light effects on phytoplankton photosynthesis performance in the southern East China Sea north of Taiwan. Bot. Bull. Acad. Sin. 37: 133-140.

Smith DW, Piedrahita RH (1988). The relationship between phytoplankton and dissolved oxygen in fish ponds. Aquac. 68: 249265.

Talling JF (1966). Photosynthetic behavior in stratified and unstratified lake populations of a plankton diatom. Freshwater Biol. 54: 99-127.

Tundisi JG, Sampaio EV, Rocha O, Matsumura-Tundisi T (2002). Compostion and abundance of zooplankton and size fractionation of the phytoplanktonic community in several reservoirs of Paranapanema River, Brazil. Braz. J. Biol. 62: 525-545.

Wetzel RG (2001). Limnology Lakes and Rivers ecosystems, San Diego Academic press p. 1006.

Wetzel RG, Likens E (1991). Limnological analysis $2^{\text {nd }}$ Edition. SpringerVerlag. New York. 